\title{
Barulho nas ruas escuras: Estilo de vida e redes sociais nos agrupamentos roqueiros
}

Noise in Dark Streets: Lifestyle and Social Networks in Rocker Groups

Tapage dans les rues sombres: Style de vie et réseaux sociaux de bandes de rockers

Irapuan Peixoto Lima Filho

\section{OpenEdition}

Journals

Edição electrónica

URL: http://journals.openedition.org/rccs/6239

DOl: $10.4000 /$ rccs.6239

ISSN: 2182-7435

Editora

Centro de Estudos Sociais da Universidade de Coimbra

Edição impressa

Data de publição: 1 Maio 2016

Paginação: 105-136

ISSN: 0254-1106

\section{Refêrencia eletrónica}

Irapuan Peixoto Lima Filho, "Barulho nas ruas escuras: Estilo de vida e redes sociais nos

agrupamentos roqueiros », Revista Crítica de Ciências Sociais [Online], 109 | 2016, colocado online no

dia 18 maio 2016, criado a 19 abril 2019. URL : http://journals.openedition.org/rccs/6239; DOI :

$10.4000 /$ rccs. 6239

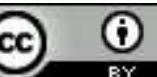




\section{Barulho nas ruas escuras: Estilo de vida e redes sociais nos agrupamentos roqueiros}

Esta pesquisa procurou investigar a formação de agrupamentos de roqueiros, fãs do gênero musical rock, na cidade de Fortaleza, Ceará, Brasil, ao longo dos anos 2000. Constatou-se que estes professam um estilo de vida próprio, que se expressa por formas de pensar, valores morais e normas de comportamento. Movimentam mais do que cenas musicais: constroem uma rede social, chamada de rede roqueira, que se capilariza por bairros "ricos" e periferias. A organização em rede permite, ainda, a formação do que chamamos de agrupamentos, coletivos que subdividem os adeptos em várias vertentes musicais, como metaleiros, alternativos, punks, hardcores, emos, bluseiros, etc. Estes não exibem relação necessariamente pacífica uns com os outros, abrindo o palco de disputas simbólicas por legitimidade.

Palavras-chave: estilo de vida; música e juventude; redes sociais; rock brasileiro; sociologia da música.

O presente artigo visa analisar a formação de uma movimentação social de roqueiros, ou seja, apreciadores do gênero musical chamado rock, na cidade de Fortaleza, capital do Estado do Ceará, no Brasil, percebendo como a ação dos sujeitos configura uma rede social que chamamos de rede roqueira. Isto possibilita uma série de articulações de grande impacto cultural e social, mesmo que o "ser roqueiro" naquela cidade represente uma condição outsider, conforme será explicado adiante.

A partir da pesquisa empírica, percebe-se que a citada rede é alimentada por um estilo de vida roqueiro e que o mesmo é mobilizado através dos agrupamentos: coletivos distintos nos quais se vivencia o estilo de vida roqueiro na prática. A partir dessa realidade, neste artigo pretendemos construir uma reflexão sociológica sobre a adesão aos grupos sociais e às maneiras como são articulados internamente para a expressão de um estilo de vida dado. 
Esta pesquisa iniciou-se como um projeto de doutorado em 2006, intitulado "A cena alternativa em Fortaleza: juventude e música na construção de sociabilidades, com financiamento da CAPES (Coordenação de Aperfeiçoamento de Pessoal de Nível Superior) por meio de uma bolsa de estudos, e resultou em uma tese publicada como livro (Lima Filho, 2013), embora continue de modo intermitente desde então. Foram realizados visitas a eventos, shows e festas; entrevistas, conversas informais; pesquisa documental; análise de CD e vídeos; e uso de redes sociais virtuais.

\section{A rede roqueira em Fortaleza}

Fortaleza está no Nordeste brasileiro, sendo a quinta maior cidade do país, com uma população de 2571896 habitantes e densidade demográfica de $7786,44 \mathrm{hab} / \mathrm{km}^{2}$, a maior dentre as capitais do país (IBGE, 2015). A cidade é polo da Região Metropolitana de Fortaleza (RMF), que reúne 19 municípios e uma população total de 3949974 habitantes.

Embora não goze da força econômica de outras capitais de porte semelhante, ${ }^{1}$ Fortaleza é uma metrópole regional, com grande importância e influência em estados vizinhos, concentrando ampla malha de serviços, indústria e comércio (Costa e Pequeno, 2015; Bernal, 2004). Quando afirmamos isso, falamos do tipo de cidade que aparece na fronteira entre a metrópole global (mais comum à teorização sociológica) e o mundo "estritamente" local das pequenas comunidades. Algo que nos remete à reflexão de Bhabha (1998) quando afirma que a relação entre o "global" e o "local", chamada de "fronteira", deveria ser a principal preocupação da sociologia.

Neste sentido, mesmo com destaque na região Nordeste do país, Fortaleza está distante do eixo de poder (econômico e cultural) do Brasil "do sul", mais famoso internacionalmente, como Rio de Janeiro e São Paulo. Entretanto, por meio de sua grandeza populacional e situação socioeconômica, Fortaleza pode ser pensada como uma metrópole e, por isso, conecta-se às problemáticas globais.

Isto pode ser percebido também no âmbito cultural. Um movimento de rock (global) em uma realidade (local) como a de Fortaleza enseja grandes reflexões sociológicas. Ainda mais quando tal musicalidade cumpre função "marginalizada" dentro do sistema de produção cultural e de entretenimento

\footnotetext{
${ }^{1}$ Não apenas em "tamanho", Fortaleza destaca-se como a cidade mais rica da região Nordeste do Brasil, com Produto Interno Bruno (PIB) de R \$ 43,4 biliões. O Nordeste compõe nove estados brasileiros, dentre os quais Bahia e Pernambuco (IBGE, 2015).
} 
na cidade, onde o forró, ${ }^{2}$ domina o entretenimento musical local. Algumas das bandas de forró de Fortaleza fazem sucesso nacional. ${ }^{3}$ Por isso, a cidade comporta circuito expressivo de bandas, festas, shows, casas de espetáculos, programas de rádio e TV, estúdios de gravação e lançamento de CD envolvendo o forró. Tal tipo de música é consumida à profusão e é traço cultural fortíssimo do fortalezense médio.

Por isso, soa estranho, mesmo ao morador de Fortaleza, pensar em um "grande" movimento de rock na cidade. Ele existe, mas ocupa posição marginal nos meios de comunicação de massa locais e mais ainda no imaginário do fortalezense.

Em vista da hegemonia cultural do forró, os roqueiros de Fortaleza são percebidos e se percebem como outsiders, "fora do sistema", marginalizados e estigmatizados. Ainda assim, por meio da rede roqueira, articulam considerável movimentação que resulta não somente na formação de bandas e das festas nas quais tocam; mas um circuito maior, com festivais, lojas, promotoras de eventos, produtoras culturais, estúdios musicais, gravações de discos e vídeos.

Equacionar o tamanho do que chamo de rede roqueira é difícil. ${ }^{4}$ Por isso, foi necessário criar uma maneira de dimensioná-la por meio de um levantamento exaustivo de bandas na cidade. Escolheram-se os conjuntos musicais porque necessitam de espaços para ensaiar e se apresentar, o que serve de catalisador de festas e shows.

Tal levantamento se deu por vários meios: cartazes de festas, panfletos, reportagens de jornal, sites na internet, blogues, portais de distribuição de arquivos digitais, menções em conversas e entrevistas, etc. Mesmo ciente dos limites de tal método, ${ }^{5}$ foi possível aferir a existência do expressivo

\footnotetext{
${ }^{2} \mathrm{O}$ forró é um gênero musical popular nascido na região Nordeste (especialmente no ambiente rural) pautado por ritmo cadenciado e forte swing, o que o torna dançante. Por isso, forró pode ser tanto a música, quanto a festa decorrente. A instrumentação básica do gênero é realizada com o trio de sanfona (acordeão), zabumba e triângulo (dois instrumentos rústicos de percussão). Desde a década de 1990, o gênero foi "modernizado" com instrumentos elétricos, como guitarra, baixo, bateria, teclados e saxofone, dando origem ao chamado forró eletrônico, que é a vertente mais popular nas áreas urbanas.

${ }_{3}^{3}$ São exemplos dessas bandas: Aviões do Forró, Forró Moral, Garota Safada e o cantor Wesley Safadão, atualmente um dos mais populares do Brasil.

${ }^{4}$ A contagem precisa envolveria uma pesquisa de porte muito maior do que o permitido pelas condições atuais, como realizar um senso com os participantes.

5 Sabe-se que esse número pode ser ainda maior, tendo em vista que essa é a lista de bandas às quais foi possível o pesquisador ter acesso. Também é preciso levar em consideração que algumas dessas bandas têm existências paralelas a outras, como projetos paralelos ou temporais, por exemplo. Devido à instabilidade da carreira de músico em termos financeiros, muitos tocam em mais de uma banda ao mesmo tempo e até algumas bandas se apresentam com mais de um nome para direcionar sua musicalidade a fins pragmáticos.
} 
número de 411 bandas de rock ativas em Fortaleza entre os anos de 2000 e $2010 .^{6}$

Se existem bandas são necessários locais para que as mesmas se apresentem e que os sujeitos que gostem desse tipo de musicalidade se encontrem. Com isso, usando mais ou menos as mesmas fontes elencadas, foi possível fazer levantamento de 73 espaços da cidade utilizados com alguma frequência pela rede roqueira no mesmo período de tempo. Estes espaços incluem não somente abrigos de festas e shows (em bares, boates e casas de concerto), mas especialmente, locais de encontro nos quais se criam laços de sociabilidade, como praças públicas e lojas de discos e produtos relacionados.

É importante frisar que pensamos tais lugares dentro da concepção sintetizada por Certeau (1996) de que um espaço é um lugar cujo sentido é construído por seus frequentadores, de modo que passam a ter significação diferenciada. Por isso os chamamos de espaços roqueiros. O curioso acerca desse levantamento é que tais espaços se espalham por várias zonas da cidade e não se restringem a bairros de classe média ou de melhor infraestrutura, ocorrendo também, mesmo de modo limitado, em bairros das periferias.

Este detalhe é importante porque, conforme se verificou nas entrevistas e conversas ao longo da pesquisa, ainda existe a noção nativa de que a maior parte da movimentação roqueira ocorre na região leste da cidade, ou seja, os bairros "nobres" próximos ao mar. Contudo, o levantamento aqui empreendido demonstra que, pelo menos nos últimos anos, há expansão da rede roqueira em direção ao oeste e ao sul, atingindo de maneira expressiva as periferias.

Esse pensamento exigiu a comparação dos espaços roqueiros de 2000-2015 com um período anterior. A pesquisa demonstra que as movimentações de rock que vão resultar na rede roqueira aqui descrita originam-se entre as décadas de 1980 e $1990 .^{7}$ Quando se observa a distribuição territorial nos momentos citados, percebe-se a descentralização dos espaços roqueiros do leste para as periferias, conforme se pode verificar na Figura 1.

\footnotetext{
${ }^{6}$ Para exercício meramente ilustrativo e com escolha subjetiva, vão alguns dos exemplos dessas bandas: 2Fuzz, 69\% Love, A Trigger to Forget, Alegoria da Caverna, Blues Label, Bonecas da Barra, Born Suffer and Die, Caco de Vidro, Café Colômbia, Cidadão Instigado, Darkside, Dead Leaves, Drive Sex, Enverso, Falacia, George Belasco \& o Cão Andaluz, Insanity, Jonata Doll e os Garotos Solventes, Joseph K?, Moço Velho, Obskure, Quarto das Cinzas, Rubber Soul, Scatalogic Madness Possesion, Selvagens à Procura de Lei, The Good Garden, Transacionais, Vulcani, dentre outras. Lembramos que os nomes das bandas são afirmações e que estão carregadas de sentidos, tal qual analisado por Pais (2006). A lista completa das bandas está em Lima Filho (2013).

${ }^{7}$ Apesar de existirem evidências de movimentação roqueira em Fortaleza desde a década de 1960 (Castro, 2008), nossa pesquisa demonstrou que a articulação se intensifica nas décadas de 1980 e 90, quando são lançadas as bases fundamentais do que chamamos de rede roqueira. Há uma descrição sintética desse movimento em Lima Filho (2013).
} 

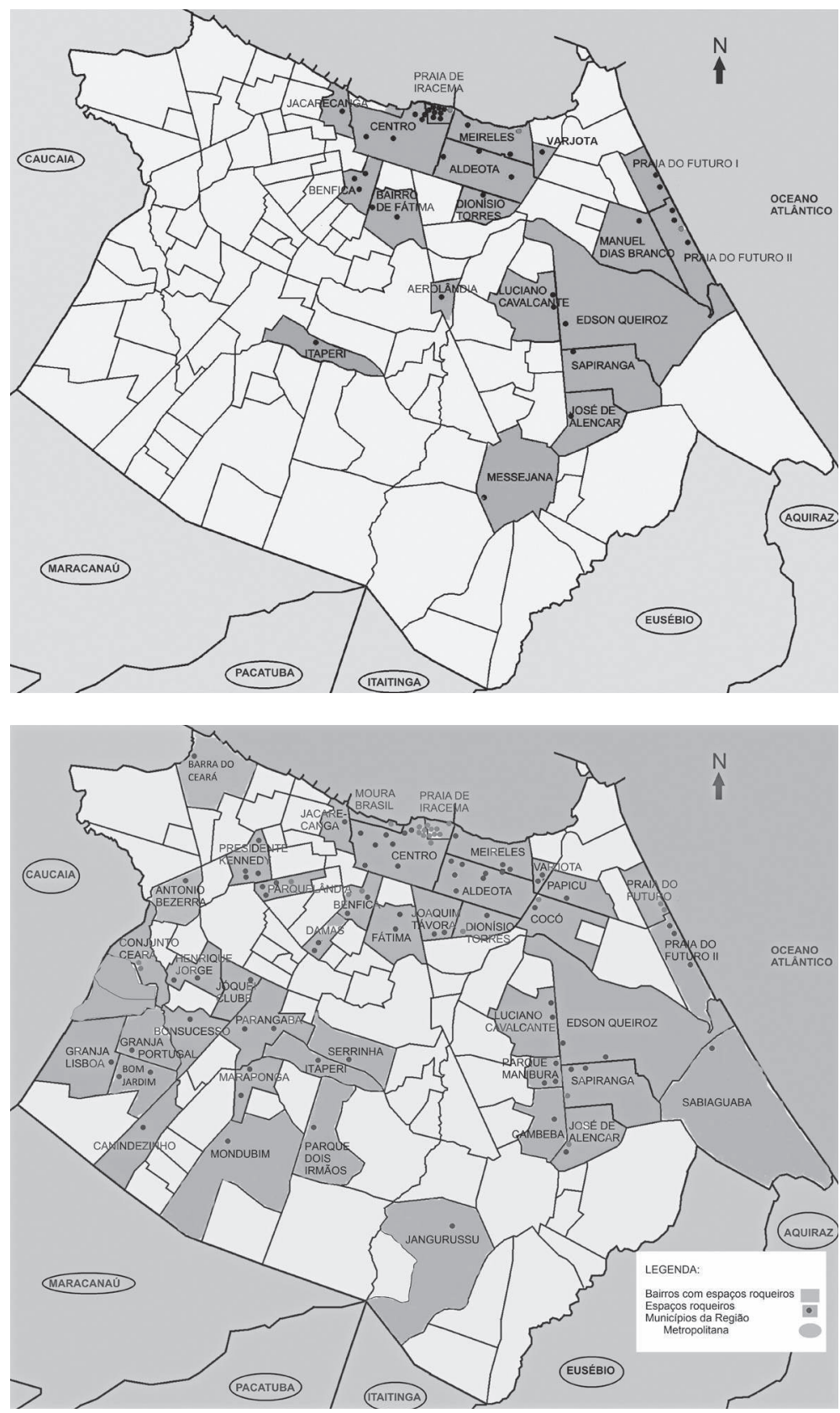

FIGURA 1 - Espaços roqueiros em Fortaleza - comparação entre os anos 1980-90 e 2015

Fonte: Elaborado pelo autor. 
A movimentação nesses espaços se intensifica porque há um alto grau de articulação gerado pelos atores sociais envolvidos. Desse modo, além dos sujeitos "tradicionais" de público e artistas, aparecem outros atores que tornam tal processo possível, mais bem organizado e amplificado.

Como o rock é um gênero musical "não consensual" em Fortaleza, não é historicamente alvo de investimentos do setor empresarial responsável pelo fomento do lazer da cidade. O capital financeiro movimentado para as festas de forró não migra para o rock. Assim, os roqueiros cedo tomaram para si a responsabilidade de viabilizar o próprio lazer, o que os levou a considerável grau de articulação e organização, mesmo com carência de capital econômico envolvido. Essa disposição é parte mesma do ideário do rock, do qual um dos lemas mais famosos é o do-it-yourself. ${ }^{8}$

Nas entrevistas com músicos das bandas e promotores de eventos, a ausência de capital econômico em torno das festas de rock era uma constante, e a maneira como os próprios roqueiros tomaram para si a responsabilidade de prover a infraestrutura necessária manifestou-se na formação de empresas de produção, lojas de discos e associações. A título de exemplo, o líder da banda Switch Stance, Maurílio Fernandes, montou a empresa Empire Records, em 2001, que de uma gravadora de discos evoluiu para promotora de eventos e proprietária de bares e casas de shows, como o Let's Go Bar.

Outras formas de associação estão presentes, além da empresa capitalista: em 1998, os membros de várias bandas de heavy metal formaram a Associação Cearense Cultural de Rock (ACR), que atua como promotora de eventos (como o Festival Forcaos, que teve 16 edições até agora) e também produtora, promovendo parcerias com o Estado por meio da concorrência em editais de financiamento cultural que resultam em shows, discos e vídeos. De modo similar à ACR, existem outros coletivos organizados a partir das bandas, como o Movimento Independente Rock e Cultura (MIRC), fundado em 2006; e a Cooperativa Underground do Bom Jardim (CUNDER), fundada em 2005, que se articulou por meio da Panela Rock, que capitaneou gravadora, produtora e casa de shows e hoje é ativa por meio da Toca Good Garden.

$\mathrm{Na}$ ausência de capital econômico, os roqueiros recorrem a diversas estratégias, seja realizando festas autofinanciadas por meio da cobrança de ingressos (e na qual assumem os riscos), seja usando das políticas públicas de financiamento cultural do Governo do Estado do Ceará ou da Prefeitura Municipal de Fortaleza. Neste caso, a ação de coletivos como ACR, MIRC e CUNDER terminaram por profissionalizar a participação nessas

\footnotetext{
8 "Faça você mesmo": lema do movimento punk, que se originou do rock, especialmente, no fim dos anos 1970, vide McNeil e McGain (1997).
} 
concorrências, permitindo maior acesso ao financiamento público e, em consequência, a realização de um número maior de ações.

Chamamos essa movimentação de rede porque consideramos a articulação existente entre atores sociais específicos que, por meio de ações complementares, formam um todo não coeso, mas articulado, cujas ligações potencializam o alcance das ações e suas consequências. Existe o pensamento de que o incremento da tecnologia nas últimas décadas, especialmente a computacional, impulsionou a análise social para também entender a própria sociedade como uma rede integrada, como se percebe em Castells (2009) e Duarte e Frey (2008).

Souza e Quandt (2008) percebem que as redes culturais são mais coesas do que as econômicas, principalmente aquelas que se organizam em espaço físico próximo, pois garantem maior conectividade entre seus atores, uma reflexão que também se encontra em Castells (2009), que ressalta o aspecto da identidade operacionalizado por essas redes. Para este autor, o que mobiliza os agentes sociais na contemporaneidade são as representações que têm de si mesmos, fortalecendo, portanto, o aspecto de autoidentificação e o sentimento de pertença gerado pela vinculação a grupos que partilham dos mesmos signos.

Em Fortaleza, a movimentação em torno do rock gera produto similar, com a organização se distribuindo por tipos distintos de atores que promovem ações complementares e articuladas, formando uma rede com o público, artistas, articuladores, responsáveis por infraestruturas de apoio e sedes de eventos e alimentadores de conteúdo.

Os articuladores são responsáveis por colocar as bandas em movimento, por meio da promoção de shows e festas, quase sempre organizadas através de empresas e produtoras culturais, mas também por entidades associativas. Fazem a ponte entre os artistas e outros dois atores fundamentais da rede: os responsáveis pelas sedes de eventos e festas, como bares, restaurantes, boates, clubes e casas de shows; e os fornecedores da infraestrutura de apoio, aqueles envolvidos com estúdios de ensaio e gravação, que fazem manutenção de instrumentos e que disponibilizam equipamentos para aluguel ou uso. Também estão nesta categoria os envolvidos nas lojas que comercializam os produtos relacionados ao rock (roupas, acessórios, CD, DVD, etc.), pois como será mencionado adiante, o aspecto visual e de adereços é fundamental à figura do roqueiro.

Tendo em vista a amplitude da rede mundial de computadores, os alimentadores de conteúdo da internet também são pensados como atores à parte,

\footnotetext{
${ }^{9}$ Estamos cientes de que essa percepção nos leva a uma reflexão sobre capital social, entretanto, este não é objetivo de nosso estudo por hora.
} 
com os sujeitos ativos em mídias que dão espaço ao rock (rádio, TV, jornais impressos, sites). Neste caso, temos também sites de trocas de arquivos e as redes virtuais de relacionamento, como o Facebook. ${ }^{10}$

Trabalhando em conjunto, público, bandas, articuladores, responsáveis por sedes de eventos e infraestruturas de apoio e alimentadores de conteúdo na internet terminam formando a rede roqueira de Fortaleza, que promove a sociabilidade de milhares de jovens por meio de seus desdobramentos. Uma visualização da rede encontra-se representada na Figura 2.

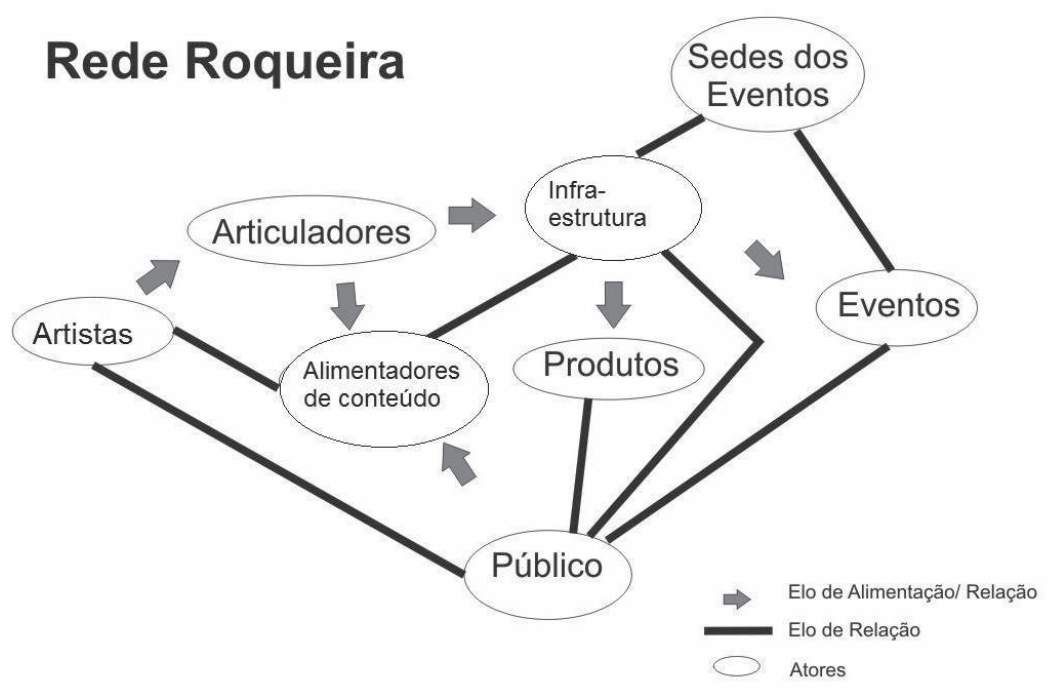

FIGURA 2 - A rede roqueira e suas articulações

Fonte: Elaborado pelo autor.

$\mathrm{O}$ aspecto endógeno da rede, com a maior parte de seus atores formada quase exclusivamente por roqueiros, é algo que se destaca. Mesmo a articulação financeira, por meio das empresas, é realizada por eles próprios. Além de alguns pequenos investidores (na figura de donos de bares, por exemplo), praticamente o único parceiro externo à rede é o Estado.

\footnotetext{
${ }^{10} \mathrm{Na}$ época de expansão da rede Orkut, principalmente entre os anos de 2004 e 2007, as "comunidades" daquela rede virtual foram fundamentais para aglutinação de vários grupos roqueiros, por exemplo o reagrupamento de metaleiros oriundos dos anos 1980. Mais detalhes em Lima Filho (2013).
} 
Também é importante frisar, como já escrito, que tal movimentação não se faz somente em festas ou eventos. Parte significativa do público que os frequenta também mantém relações de sociabilidade mais corriqueiras, orientadas em torno do rock em momentos não festivos, como reuniões em espaços públicos para discutir sobre suas músicas e bandas favoritas, trocar material e experiências, namorar ou apenas ocupar o tempo. As turmas servem como orientadores de sociabilidades dos jovens e são elementos primordiais do sentimento de pertença ao ser roqueiro, algo que será aprofundado adiante.

A rede roqueira assume tal feição em meio à década de 2000, quando as condições objetivas permitem à articulação atingir esse nível. A existência desse esquema geral não significa que os atores ou as estruturas sejam fixos, já que a inconstância é parte essencial de uma rede na qual o capital financeiro não é abundante.

Assim, bares, lojas e promotoras de eventos não raro têm vida curta, já que não conseguem sobreviver às intempéries do mercado capitalista. Isto explica o fato de espaços fundamentais à rede em algum momento de tempo - como Noise3D Club, Hey! Ho! Rock Bar, Casarão do Rock, Canto das Tribos, etc. ${ }^{11}$ - não durem mais do que alguns anos. Existem exceções, também, como a loja Opus, que comercializa produtos relacionados ao rock (CD, roupas, acessórios) desde 1984.

A articulação da rede gera "produtos", sejam festivais e festas, sejam composições, CD, DVD, videoclipes, documentários, etc. Essa produção alimenta o chamado mercado independente, que existe para além das grandes gravadoras ou da grande mídia. Os eventos podem ser classificados no tipo cotidiano (apresentações musicais corriqueiras nos fins de semana em bares e boates), mas também de um tipo mais específico, como os festivais de música: Forcaos, Ponto.CE, Rock Cordel, Ceará In Rock e outros.

Entendendo a dimensão geral da rede e quais seus atores principais, passemos à análise dos aspectos que embasam sua formação.

\section{A movimentação da rede roqueira e seus espaços}

A Figura 1 demonstrou a expansão da rede roqueira e sua movimentação pelas periferias de Fortaleza. A ocupação desses espaços demonstra ação

\footnotetext{
${ }^{11}$ Como exemplo de persistência, mesmo quando alguns estabelecimentos se encerram, podem ter sobrevida por causa das articulações da rede. Após o Noise 3D fechar as portas em 2007, seus proprietários permaneceram realizando festas em locais itinerantes, principalmente, outras boates da cidade. O Hey!Ho! encerrou suas atividades em 2011, porém alguns de seus sócios continuaram a promover eventos por meio de uma produtora e, em 2015, abriram uma nova casa de shows chamada Let's Go, na mesma vizinhança do antigo clube.
} 
de resistência, já que manter a recorrência de festas e shows em bairros de baixa renda e com poucas infraestruturas requer muita habilidade por parte dos agentes essenciais dessa articulação. $\mathrm{O}$ discurso do roqueiro, tomado nas entrevistas e na observação do campo, realça um aspecto de "rebeldia" vinculado ao rock, que se associa à ideia de que é um sujeito outsider dentro de um sistema repressor.

A maneira como os roqueiros elaboram esse discurso está relacionada a muitos fatores, que incluem o fato de viverem numa situação social desfavorável economicamente, ao mesmo tempo em que se envolvem com um gênero musical estranho ao ambiente em que habitam, seja as periferias ou as cidades do interior do Ceará.

[Meus amigos] Eram pessoas que curtiam um estilo de música [diferente] na periferia, que andavam de preto em uma periferia, que tinham um estilo de cabelo diferente numa periferia... Então, essa característica, pelo local, isso já era muita coisa, já era transgressão, sabe? O simples fato de você ouvir coisas como [a banda] Offspring já era muito, já perturbava a cabeça de muita gente. ${ }^{12}$ (Daniel Valentim, grifos do autor) ${ }^{13}$

[Meu envolvimento inicial com o rock foi] no interior. Detalhe! [...] [A cidade de] Iguatu ${ }^{14}$ não tem, praticamente, roqueiro lá. Se tem é [tido como] marginal! (risos) Era rotulado lá, se tinha era marginal mesmo! (Adjacy Farias)

Dessa forma, o discurso do "ser roqueiro" é pautado pela condição de outsider, e encontra eco forte no fato de a rede roqueira se disseminar pelas periferias da cidade. A linguagem nativa traz a expressão "é muito rock and roll", delimitando o rock como um jeito de ser rebelde e marginal, pelo que se adequava organizar festas e shows em ruelas escuras, semipavimentadas e de pouca infraestrutura.

Portanto, é fundamental entender em que bases está assolada essa capilaridade da rede e qual o contexto social desses bairros. Em primeiro lugar, é preciso notar que Fortaleza é uma cidade de extremos e internacionalmente

\footnotetext{
${ }^{12}$ A presença maciça de roqueiros em Fortaleza ainda causa estranheza à população em geral. Foi emblemático, durante a pesquisa, o momento da fila da bilheteria do Festival Forcaos, em 22 de julho de 2007, no Centro Cultural Dragão do Mar, o maior e mais importante da cidade. Enquanto centenas de jovens vestidos de preto se aglomeravam à espera de seus ingressos, um casal de "adultos" chegou trazendo o filho para comprar suas entradas e o pai comentou em tom de piada: "Parecem um bando de coadjuvantes de um filme de terror".

${ }^{13}$ Esta fala e as seguintes são de entrevistas realizadas ao longo da pesquisa com frequentadores das festas roqueiras de Fortaleza e com membros de bandas e donos de estabelecimentos comerciais. ${ }^{14}$ Cidade a 384 km de Fortaleza e com população de 101386 mil habitantes, segundo o IBGE (2015).
} 
conhecida por sua desigualdade social. Uma metrópole que se construiu muito rapidamente, sem o devido planejamento ou preparo para tal: passando de 12 mil habitantes no início do século xIx (Lima, 2006) para 90 mil no fim daquele século; e aumentando a população 42,5 vezes ao longo do século xx, com crescimento populacional de $62,5 \%$ na década de 1970 (Costa e Pequeno, 2015). Apesar da taxa de crescimento ter se reduzido significativamente nas últimas décadas - o último Censo registrou apenas $14,51 \%$ (ibidem) - os problemas gerados por tal aumento desenfreado no passado recente, notadamente a desigualdade social e a falta de infraestrutura básica, continuam a assombrar a cidade nos dias atuais.

De um total de 119 bairros, apenas oito têm renda média mensal superior a $R \$ 2000,00$, enquanto 91 estão com média abaixo de $R \$ 500,00$. Chama a atenção a discrepância entre o bairro com maior renda ( $\mathrm{R} \$ 3659,54)$ e aquele com menor ( $R \$ 239,25)$, numa diferença de 15 vezes $^{15}$ (IPLANFOR, 2015: 93 e 94). Quanto ao Índice de Desenvolvimento Humano (IDH), há bairros da cidade com índice de 0,953 (próximos aos dos países mais ricos da Europa), enquanto outros apresentam um IDH de 0,136 (abaixo de países como a Etiópia). ${ }^{16}$

Tais características permitem visualizar duas "Fortalezas": a Zona Leste, mais rica e com melhor infraestrutura; e a Oeste, mais pobre e com infraestrutura bastante inferior. Por isso, é interessante perceber a expansão das ações da rede roqueira justamente para esta segunda região nas últimas décadas.

O que chamamos de Zona Leste é a região mais rica economicamente ${ }^{17}$ e abriga os principais equipamentos turísticos da cidade, como praias e hotéis. Foi nesta região que se desenvolveram os primeiros espaços roqueiros e outros importantes (Hey!Ho!, Canto das Tribos). Ainda hoje se encontram lá espaços de grande significação para a rede roqueira, como bares ou pubs (All Green, At Home, Boozer, Let's Go, Rota 66, Sherlock, Zug), restaurantes (Floresta, Maria Bonita), centros culturais (Dragão do Mar, Centro Cultural Banco do Nordeste), boates (Órbita), estúdios musicais (MV, Top, Agnes) e praças públicas (Praça do Dragão, Praça Portugal). Esses espaços estão em bairros como Meireles, Aldeota e Praia de Iracema, que estão entre aqueles com maior renda familiar média, com o $1 .^{\circ}, 5 .^{\circ} \mathrm{e}$ 9. ${ }^{\circ}$ lugares, respectivamente (IPLANFOR, 2015).

\footnotetext{
${ }^{15}$ Respectivamente, os bairros Meireles e Conjunto Palmeiras.

${ }^{16}$ Dados correspondentes aos bairros Meireles e Canidezinho, respectivamente.

17 Segundo o IPLANFOR (2015), todos os 10 bairros com maior renda familiar média estão na Zona Leste: Meireles, Guararapes, Cocó, N.S. de Lourdes, Aldeota, Mucuripe, Dionísio Torres, Varjota, Praia de Iracema e Bairro de Fátima. Quanto ao IDH, repete-se a mesma situação, apenas invertendo a ordem de alguns dos bairros citados (ibidem).
} 
Se antes a movimentação era quase exclusiva nessa região da cidade, desde o início da década de 2000 percebe-se um movimento da rede espalhando-se em direção a oeste, onde se situam bairros com índices sociais bem mais negativos. Por um lado, há uma região noroeste intermediária que, por oferecer melhor infraestrutura,$^{18}$ tem condições de abrigar alguns equipamentos que servem à rede, tanto bares (Rock 80) quanto estúdios (Espinha de Peixe) e praças (Pracinha do North Shopping, Praça da Gentilândia). Mas por outro, a rede se desenvolve de modo intenso em bairros que estão entre os que apresentam renda familiar média mais baixa na cidade, como Henrique Jorge e Bom Sucesso (71. ${ }^{\circ}$ e $95 .^{\circ}$ do ranking), que são a base territorial do MIRC; ou Bom Jardim e Canindezinho $\left(110 .^{\circ}\right.$ e $\left.117 .^{\circ}\right)$ área de ação da CUNDER e Panela Rock. Esta última região, inclusive, oferecendo espaços para as bandas se apresentarem, seja por meio de parcerias com o Estado (Centro Cultural Bom Jardim e Shopping Solidário Bom Mix), seja executado diretamente pelo movimento, como o extinto Espaço Panela Rock e o atual Toca Good Garden.

Também não podemos deixar de notar a ampliação da rede em uma região sudeste da cidade, em bairros que, apesar de fracos índices sociais, vêm passando por um processo de "enobrecimento" causado pela ação da especulação imobiliária. Todavia, é na Zona Oeste mais periférica que se encontra parte da movimentação mais intensa da rede nos dias atuais. ${ }^{19}$

O uso dos espaços roqueiros não é aleatório nem irrefletido: os próprios roqueiros estabelecem diretrizes e hierarquias. Assim, restaurantes na Zona Leste que tenham programação constante de bandas de rock, como o Floresta, no bairro Aldeota, são frequentados por público abrangente que pode ouvir esse gênero musical de vez em quando; por isso, tem uma classificação de baixo valor simbólico por parte daqueles mais relacionados ao estilo de vida roqueiro, àqueles que se dizem "muito rock and roll". O mesmo vale para a casa de shows Siará Hall (que abriga qualquer tipo de música) na Zona Sudeste.

De modo oposto, o bar Rock 80 na Parquelândia (Zona Noroeste), eventos do MIRC e shows na Toca Good Garden, na Zona Oeste, têm "aprovação" no sistema de classificação próprio dos roqueiros. Existem, portanto, os lugares "mais rock and roll", que são aqueles espalhados pelas periferias e que promovem o barulho nas ruas escuras.

\footnotetext{
${ }^{18}$ Esta região se desenvolve no entorno da Av. Bezerra de Menezes, que é um corredor comercial, bancário e de serviços de grande importância na cidade.

19 Existem, claro, outras movimentações roqueiras além destas citadas, como se pode notar na Figura 1. Destaque para o movimento Ensaio Rock, que ocupa a Praça da Cruz Grande no bairro Serrinha e promove shows e festivais, algumas vezes em parceria com o Estado, outras por conta própria.
} 


\section{O ser roqueiro, rebeldia e transgressão}

Ser roqueiro envolve a vivência de uma série de signos. As andanças de pesquisador em meio à movimentação da rede roqueira em Fortaleza permitem perceber que esses sujeitos desenvolvem forte adesão ao código de símbolos, valores e normas de comportamento construídos pelo que chamamos de estilo de vida roqueiro. A compreensão do rock como "mais do que música" não é nova e envolve extensa bibliografia (Frith, 1981, 1988; Muggiati, 1983; Friedlander, 2002; Miles, 2009), mas também é algo incorporado no discurso dos próprios roqueiros. "Ser roqueiro" é uma autoafirmação e não uma classificação do pesquisador. Além disso, são os próprios interlocutores quem constroem uma significação especial em torno do que são:

Acho que o reggae não tem aquela imposição que o rock impõe: se você é roqueiro, você tem que ter um ideal. [...] O rock meio que impõe essa ideologia [...]. Não tem como não ter posição, tem que ter ideologia política. [...] Todas as coisas que eu faço, eu procuro ser muito rock and roll. (Donizete Araújo, grifos do autor)

É interessante notar a vinculação que os próprios agentes fazem de sua atitude roqueira com a noção de ideologia política, entendendo a participação política num sentido aristotélico, mais amplo: ser roqueiro por si só já é afrontar a sociedade, pois a cosmologia desse gênero musical traz em si símbolos de contestação social que vão desde o discurso crítico direto (em letras de músicas ou em depoimentos e ações de artistas) e passam também pelo modo de vestir, de usar os cortes de cabelo etc.

O rock é a música de protesto por excelência. [...] Aí, junta a música com a ideologia e aí vai. [...] Ideologia, assim, mais no modo de pensar em geral. [...] Eu acho que o rock já é rebelde por natureza, né? (risos) Você formar uma banda de rock já é uma rebeldia. É uma loucura pros pais: "esse menino não quer nada!" (risos). (Adjacy Farias, grifos do autor)

Neste caso, "ser muito rock and roll" é não apenas um lema, mas a expressão de um modo de ser. É procurar expressar um conjunto de códigos amarrados por meio de valores morais e normas de comportamento baseados no imaginário que o rock, enquanto movimento cultural, e a mídia construíram em torno do ser roqueiro. Discos, filmes, jornais, revistas e, especialmente, transmissão oral construíram ao longo de décadas uma série de códigos muito específicos em torno da figura esperada de um roqueiro.

A ideia de transgressão social passada por ídolos do passado, como Jim Morrison (vocalista da banda The Doors), do guitarrista Jimi Hendrix, 
de John Lennon (ex-membro dos Beatles), de Keith Richards (guitarrista dos Rolling Stones), dentre tantos outros, ecoa por meio das gerações seguintes, dentro de um processo constante de reconstrução, ressignificação, reimaginação. Tais artistas ficaram famosos por usarem drogas, serem presos por comportamento julgado inadequado, fizeram canções de cunho crítico e transformaram suas próprias biografias em performances artísticas representantes de um movimento de ruptura com o status quo. Frith (1988) relaciona Jim Morrison como figura-chave do rock por causa de sua performance, de sua visão como poeta perdido, boêmio, mas fundamentalmente, por sua autoindulgência e pelo facto de o artista ter consciência da sua própria importância e ter promovido sua carreira e sua arte a partir da noção de que "estava fazendo a diferença". Um tipo de sensação que pode ser percebida em vários outros.

Desse modo, Frith (1981) relaciona a movimentação roqueira da década de 1960 como um gesto político de ruptura cultural, baseada em grandes mudanças sociais nas sociedades ocidentais, marcadas pela emergência de novos meios de comunicação de massa (e aperfeiçoamento dos antigos), de novos movimentos políticos e da eclosão da juventude como um ator protagonista dentro do panorama social, fenômeno também percebido por Hobsbawm (1997) e Morin (1999).

Para Frith (1981), essa juventude representa uma ruptura e novo olhar, e o rock foi um dos principais meios de expressão e autoafirmação dessa concepção. Segundo o autor, ao romper com os padrões morais das gerações anteriores, essa juventude foi vinculada à delinquência, porém, ela tem que ser entendida como um tipo de concepção ideológica, na qual se vê o fenômeno (especialmente nos EUA e Grã-Bretanha) através do qual os jovens de classe média adquirem valores geralmente associados às classes mais baixas, como busca de excitação, rupturas, indulgência, autonomia, etc. (ibidem: 190). Essa juventude estava associada à noção de contracultura e, também, do movimento estudantil, consolidando, segundo o autor,

Novos estilos de consumo (consumo de drogas, em particular), novas noções de liberdade pessoal (particularmente, liberdade sexual) e uma compreensão mais crítica do "sistema". Com isso, houve experiências que marcaram uma consciência geracional, experiências que não podem ser separadas do significado de rock 'n' roll. (idem, 1981: 193-194) ${ }^{20}$

${ }^{20}$ Tradução do autor. 
Para Roszak (1972), parcela significativa dessa juventude parecia negar o sistema técnico-burocrático de suas sociedades em prol de alternativas oriundas das manifestações culturais, artísticas e espirituais, daí o termo contracultura que se consolidou para designar movimentos como a literatura beatnick, a nouvelle vague do cinema francês, o cinema de autor nos Estados Unidos (ou Nova Hollywood), a pop art, o psicodelismo, o cinema novo, a tropicália; da qual o rock foi um dos protagonistas.

Pensando nos termos de Bourdieu (1992), esses movimentos questionavam as hierarquias dos campos simbólicos em que atuavam e se posicionavam contra eles. O rock surgiu dentro da indústria cultural voltada à massificação e à padronização, como conceituaram Horkheimer e Adorno (2002). Entretanto, mesmo mantendo parte dessa lógica, aquele gênero musical buscava romper com um sistema de classificação fortemente orientado pela noção de belo, consolidada ainda pela música clássica.

Como percebem autores como Friedlander (2002) e MacDonald (2008), o rock subverteu esse campo por meio da instituição da distorção (especialmente do som da guitarra) - algo tido como "defeito", "saturação", algo inapropriado - como um de seus elementos fundamentais. $\mathrm{O}$ discurso explícito de ruptura com o que veio antes ${ }^{21}$ também confere esse elemento de desconstrução da hierarquia dos capitais simbólicos que regiam o campo musical e que, vistos em retrospectiva, foram bem-sucedidos, quando o rock se torna o principal mercado musical mundial, já no início dos anos 1970, como diz Hobsbawm (1996).

Para além dos aspectos estéticos, não é menos importante a construção de um tipo de "nova moral" que acompanhava os produtores e consumidores de rock, sintetizadas no apelo simbólico aos lemas do amor livre e suas variantes: "paz e amor" ou "faça amor, não faça a guerra".

No contexto da década de sessenta, o rock deixa de ser somente um gênero da música popular que [...] expressava simbolicamente os conflitos entre as gerações, sobretudo, aqueles relativos à renúncia dos jovens de adentrar no "mundo adulto".

[...] De fato, a década de sessenta, principalmente em sua segunda metade, ficou marcada na história do século XX como um momento no qual a possibilidade de uma "revolução juvenil" obteve seu maior êxito, apesar de não ter realmente acontecido. (Sarlo, 1997: 28)

${ }^{21}$ É possível ver o discurso dos próprios artistas roqueiros em meios como as entrevistas à revista Rolling Stone, copiladas por Wenner e Levy (2008). 
Com isso, o roqueiro enquanto tipo ideal é um sujeito rebelde que contesta os valores do "sistema", ou seja, da ordem instituída, do status quo, do establishment. O imaginário do roqueiro reproduzido pela sociedade e por eles mesmos é próximo ao outsider de Elias e Scotson (2000): parte de um grupo social que compartilha valores diferenciados dos estabelecidos de modo geral na sociedade e se opõem a eles; embora neste caso, não tanto num desejo de ascender aos valores dos dominantes, como na obra da dupla, mas muito mais interessados em fundar uma nova ordem.

Os roqueiros prosseguiram mimetizando essa atitude e transformando sua ação cotidiana em uma performance que os vincula a toda essa cosmologia roqueira. Eles consolidaram algo como a visão de mundo da qual fala Weber (1991). O que quer que seja essa postura "rebelde" na prática é algo menos nítido, porém constitui um discurso muito forte por parte de seus agentes. Os roqueiros com quem travei contato na pesquisa esperam - de si e de seus pares - uma postura "rebelde" diante da vida, que pode se refletir particularmente nas relações contra a autoridade, figura abstrata que em geral representa a ordem estabelecida, o "sistema" como eles dizem, e vão desde as relações familiares àquelas travadas com a escola, a igreja e até a política num sentido mais amplo.

Assim, seus relatos estão marcados pela afirmação de suas práticas particulares de rebeldia, que envolvem, não raro, "coisas pequenas" como não se submeter às ordens dos pais; ser aluno transgressor na escola; ser militante de movimentos de esquerda.

Os relatos dos interlocutores citados neste trabalho estão permeados desse tipo de narrativa "rebelde" como forma de justificar ao pesquisador porque estão "adequados" à classificação de roqueiros. Falam em ser roqueiros numa periferia (ou numa cidade do interior) que cultua gêneros musicais como forró ou RAP, no qual o rock (e o roqueiro) é um ente estranho, até certo ponto perturbador (Daniel Valentim, Amaudson Ximenes, Adjacy Farias); de ser um agente transgressor dentro do "sistema" (Donizete Araújo):;2 de praticar algumas ações de rebelião (Franzé Bezerra); ${ }^{23}$ além de carregarem o discurso (Amanda Silva e nos citados Valentim e Araújo)

\footnotetext{
${ }^{22}$ Este interlocutor trabalhou como produtor na TV Diário, emissora local famosa por ter uma programação voltada ao forró como trilha sonora em programas de auditório e apresentação de bandas. Araújo diz que trabalhou na TV como maneira de forçar para que o rock aparecesse na programação local, relatando alguns ganhos à sua causa, como o episódio do momento em que a banda Jumenta Parida, muito popular entre os roqueiros da cidade, fez sua primeira aparição na TV. ${ }^{23}$ Este interlocutor afirma que, junto a alguns amigos que eram metaleiros como ele e, portanto, brincam com os símbolos religiosos pagãos, picharam as paredes da Igreja de N. S. de Fátima, templo que recebe uma grande peregrinação religiosa em Fortaleza, com cruzes invertidas e coisas do tipo.
} 
de uma sensação de inadequação dentro da maneira como a sociedade está organizada, particularmente no que se refere a algumas instituições sociais elementares (Estado, família, escola e religião), relatando angústia, sofrimento, melancolia, depressão e raiva por esses motivos. Um deles tenta elaborar esse sentimento:

O engraçado é que essas pessoas [os roqueiros, seus amigos], elas sempre têm uma... têm uma coisa que as deixa desconectadas do mundo. É, mesmo, o outsider, né? Esses grupos, elas quase todas, essas pessoas, elas tinham essa característica. Então, são pessoas que, mesmo jovens, tinham uma experiência de vida bem peculiar, principalmente, alguns mais... geralmente mais marcado em relação à família, perdeu alguém da família de forma trágica, entendeu? Ou então, era aquela pessoa que tinha problemas em casa, tinha problemas com os pais, isso era uma coisa que eu percebo que era muito marcante, que fazia... muita gente com problema com a escola... (Daniel Valentim, grifos do autor)

$\mathrm{O}$ roqueiro se afirma rebelde, mas, ao mesmo tempo, se sente marginalizado e até mesmo estigmatizado, pensando na categorização de Goffman (1988). Porém, seu discurso regurgita tal informação, transformando a percepção do outro como "estranho" em mais um componente de sua própria identificação. Também é possível notar que muito desse "conteúdo" que os roqueiros utilizam para justificar a si mesmos como dignos de serem chamados de tal estão fortemente relacionados às biografias pessoais, no que nos lembramos de Giddens (2002), quando discute que os agentes constroem seus "calendários pessoais" que os localizam dentro de processos sociais maiores e mais complexos e norteiam suas biografias narradas e construídas.

Neste sentido, os roqueiros precisam exibir aos outros que carregam consigo os signos fundamentais que os vinculam a esta identificação. Os valores morais e regras de comportamento que compõem o universo roqueiro precisam não somente ser incorporados, mas comprovados por meio de práticas e vivências.

É necessária, então, uma série de estratégias para exibir os signos dessa rebeldia. Isso ocorre pela indumentária, por exemplo, já que o rock tem apelo visual forte, expresso por meio de roupas, acessórios, maquiagens, intervenções (piercings, tatuagens), corte de cabelo, etc. ${ }^{24}$ que geram a identificação do roqueiro como alguém vestido de cor preta, com adornos de

${ }^{24}$ Então, faz-se necessária a existência de fornecedores desses produtos, o que cria um mercado específico de consumidores desses artigos, que o fazem por meio de lojas especializadas, mantidas em sua maioria também por roqueiros. 
metal (correntes, rebites, pulseiras) e cabelos longos. Toda essa significação visual busca reforçar o elemento de desconexão e dissidência em relação ao "sistema" ou ao status quo e marcam o rock como fenômeno cultural desde o início. Como já percebera José Machado Pais:

Todas as correntes do rock [...] procuraram, no entanto, algum tipo de singularização, por simbólica que fosse. Com efeitos, jovens desses grupos actuavam como bricoleurs, apropriando-se de características que integravam num universo simbólico que lhes permitia subverter sua significação original [...]. Esses movimentos podem ser olhados como dissidentes - ao oporem-se, continuamente, ao que os nivelava e uniformizava -, mas nessas dissidências encontramos permanentes convergências. (2006: 30)

Essa dissidência do rock é encontrada em sua própria história enquanto gênero musical, criando uma rede de significados que liga os roqueiros de Fortaleza com o movimento dos anos 1950 e 60, prosseguindo até os dias de hoje. Não faz sentido falar dos roqueiros sem descrevê-los e discutir como se organizam, por isso iremos analisar os agrupamentos sociais que formam para vivenciar na prática a vinculação com a visão de mundo ao qual se sentem pertencentes.

\section{Os agrupamentos roqueiros}

Apesar de servir como eixo fundamental da visão de mundo roqueira, a rebeldia celebrada em seus discursos é deveras diversa, subjetiva e, por vezes, imprecisa. Parte disso está associada ao fato de o rock ser diversificado por natureza. Ao contrário de outros gêneros musicais, este é identificado menos por ritmo-cadência ou características melódicas-harmônicas, e muito mais pela maneira como é executado: elementos como distorção e intensidade são mais importantes do que ritmo e velocidade.

Os historiadores do rock ${ }^{25}$ costumam definir um tronco principal do gênero - o rock em si - e subdividi-lo em subgêneros. Todavia, a grande diversidade e a passagem do tempo terminaram por também subdividir os subgêneros. Exemplo é o heavy metal, subgênero do rock que surgiu nos anos 1970 e, além de ser um dos principais "galhos" da árvore genealógica do rock, o metal se subdivide em literalmente dezenas de "subsubgêneros". ${ }^{26}$

Os subgêneros e suas subdivisões se distinguem tanto - talvez menos aos ouvidos "leigos" e mais aos "especialistas" - que terminam por diferenciar,

${ }_{25}$ Vide, por exemplo, Christe (2010), Dimery (2007), Miles (2009) e Muggiati (1983).

${ }^{26}$ Alguns exemplos: heavy metal melódico, black metal, death metal, thrash metal, prog metal, grindcore, etc. 
também, seus ouvintes. A diversidade, portanto, permite ao roqueiro vivenciar a prática dos valores morais e regras de comportamento vinculadas a eles de maneiras diferentes.

Normalmente, a literatura sociológica classifica essa vivência prática por meio da nomenclatura de "tribos urbanas". No entanto, este termo não é satisfatório para descrevê-los. Da maneira como aqui exposto, é preciso compreendê-los dentro de uma significação própria, por isso construímos a nomenclatura de agrupamento para explicá-los.

A noção de agrupamento diz respeito, fundamentalmente, à vivência prática de um determinado estilo de vida no cotidiano. Tem um efeito de sociabilidade, pois está envolvida à convivência em um coletivo social, reconhecível não somente por si, mas por outros. O agrupamento é uma expressão praticada da visão de mundo que sustenta um estilo de vida particular, que é o ser roqueiro. Iremos inverter a explicação e demonstrar como funciona essa prática para somente em seguida detalhar porque se configura como um estilo de vida.

A vivência prática nos agrupamentos se dá por meio da expressão de pensamentos e comportamentos muito específicos que agregam seus sujeitos dentro de uma unidade reconhecível que, por sua vez, faz parte de um todo maior, neste caso, o próprio ser roqueiro. Ou seja, um dado estilo de vida pode agregar maneiras de vivências diferentes que, praticadas, estão vinculadas, mas se distinguem.

Usamos agrupamento porque tal condição não é satisfeita por outras categorias que existem, como a comunidade de Weber (1991), por exemplo, mesmo que deva ligações à mesma. Similarmente, usar grupo social também não é adequado, já que este é um termo muito amplo e, na maioria das vezes, usado de modo indiscriminado.

Desse modo, as considerações de Simmel (1977) sobre os grupos sociais - sua formação e manutenção - são muito úteis para pensar os agrupamentos. A categoria "tribos urbanas" pode se referir a qualquer prática unificadora ou de sociabilidade a que jovens ou outros se manifestem no tecido das grandes cidades. Ainda assim, aproveitando-se da força da palavra "tribo", pelo menos em seu sentido indígena, tal categorização é muito útil para descrever determinados fenômenos sociais, dentre os quais o da formação de gangues e galeras nas metrópoles, vide, por exemplo, Diógenes (1998). Ao fenômeno de vivência e pertença do/ao ser roqueiro, pensamos que a categorização de agrupamentos é mais adequada. Vamos descrevê-los para maior compreensão.

No âmbito da rede roqueira de Fortaleza enxergamos metaleiros, alternativos, punks, hardcores, emos, bluseiros, skinheads e alguns outros tipos 
diferenciados de experimentação do estilo de vida roqueiro. Cada um deles se diferencia porque exaltam características distintas, não apenas na musicalidade específica que os identifica, mas em valores e comportamentos também específicos que se expressam por meios visuais em indumentárias e cortes de cabelo.

Assim, o agrupamento traz algo de categoria nativa, no sentido de que esse sentimento de pertença vinculado a uma nomenclatura específica é vivenciada, expressada e defendida pelos próprios sujeitos. Os metaleiros se identificam como tal, mesmo que, como em qualquer coletivo social amplo e complexo, a própria terminologia também possa ser alvo de disputas. ${ }^{27}$ Portanto, os nomes aqui usados são a síntese possível entre as autoclassificações e a nomeação construída pela própria pesquisa.

Para sistematizar o que seja um agrupamento, o melhor é descrevê-lo. Como é preciso restringir, iremos analisar dois casos para compará-los rapidamente. Na Fortaleza dos anos 2000, dois agrupamentos roqueiros eram mais nítidos: os metaleiros e os alternativos. Os primeiros são fãs de heavy metal e expressam valores muito específicos relacionados àquela musicalidade, como afeição a temas sombrios e violentos, que remetem à imagem de anjos, demônios, monstros e outras criaturas; enquanto os alternativos são menos homogêneos e se distinguem mais por uma caracterização visual e a postura de defesa de um mercado "independente" da grande mídia.

Embora não haja uma sonoridade facilmente identificável com os alternativos, pagam determinado tributo a uma linhagem específica dentro da história do rock que advém das manifestações egressas do movimento punk. ${ }^{28}$

Em termos visuais, os metaleiros costumam apresentar um visual básico formado por jeans e camisetas pretas. Estas geralmente são estampadas com logomarcas de bandas, imagens das mesmas ou das capas de álbuns. Alguns adornos também se somam, como pulseiras, braceletes, tarraxas, cintos e rebites. Contudo, a experiência das festas ou shows permitem caracterizações mais extremas, nas quais alguns membros tentam mimetizar o vestuário que os artistas consagrados usam em videoclipes ou imagens

\footnotetext{
${ }^{27}$ No Brasil, a primeira terminologia associada àqueles que "gostam" de heavy metal foi headbangers, uma palavra inglesa ("batedores de cabeça") usada em países anglo-saxônicos. Ao longo dos anos 1980, o termo metaleiros se popularizou; contudo, uma parcela dos roqueiros mais antigos sempre teve reservas a este nome, preferindo o primeiro. Além dos dois nomes também são usados outros, como "galera do metal" ou mesmo "galera do rock metal".

${ }^{28} \mathrm{O}$ movimento punk é um corte epistemológico na história do rock. Com a ascensão do rock como o gênero musical de maior sucesso no planeta, os principais artistas transformaram-se em multimilionários nos anos 1970, o que causou descontentamento das "bases" do movimento: os fãs advindos das classes trabalhadoras começaram a não se sentir representados por aqueles. Assim, eclodiu o punk.
} 
publicitárias, o que os leva a usarem sobretudos, batas de padres, botas, coturnos, capas e maquiagem que remete a filmes de terror, com pó branco, sombras pretas nos olhos, esmaltes e batom também escuros, etc. Os cortes de cabelo geralmente estão voltados aos fios longos tanto para elementos do sexo masculino como feminino. Embora os cabelos longos lisos sejam os mais valorizados, o uso de grandes cachos também é permitido.

Os alternativos, por sua vez, apresentavam-se nas festas com caracterizações bem distintas: usavam um tipo de vestuário de grande influência da moda britânica, destacando jaquetas, casacos, echarpes, chapéus, estampas em xadrez, pulôveres, camurça, tênis da marca All Star, calças justas, sobreposição de peças, etc. Alguns adornos como lenços e óculos de armações grandes e grossas também eram muito bem-vindos. Distintos dos outros, os alternativos valorizavam o uso de cores, especialmente as berrantes, o que demarca ruptura com a sobriedade escura do rock no geral. A performance visual também tinha seus casos extremos, medidos pela quantidade desses itens utilizados, que podiam variar de alguns dos citados à maioria. $\mathrm{O}$ uso exagerado da vestimenta é o que demarca os extremos. Quanto aos cortes de cabelo, a valorização é a repetição dos cortes em franja e volume dos anos 1960, embora agora um pouco mais estilizados. O uso de tintura nos fios também demarca certo diferencial.

Em termos de valores, a grande marca dos alternativos é a oposição ao mercado tradicional, aos grandes sucessos, ao consumo de massa. Preferir os nichos de mercado, as linhas alternativas de mercado, o consumo independente, lhes garante outra marca de distinção. Também têm predisposição a buscarem sonoridades "diferentes" ou "exóticas", não raro dando espaço para regionalismos. ${ }^{29}$ Apesar disso, há preferência pela sonoridade tipicamente inglesa do rock. ${ }^{30}$ Parte considerável dessa sonoridade de referência traz a expressão de melancolia, o que é outra postura notável entre aqueles que aderem a tal agrupamento. O "desencaixe" do mundo já narrado por alguns roqueiros é particularmente forte aqui, de modo que é comum no discurso (e nas letras das canções!) a referência ao uso de medicamentos fortes e controlados (antidepressivos em especial).

\footnotetext{
${ }^{29} \mathrm{Na}$ verdade, identificamos quatro subdivisões entre os alternativos de Fortaleza. Os indies (mais ligados ao indie rock e, em alguns sentidos, apresentando uma radicalização das descrições apresentadas), os góticos (que ressaltam aspectos "sombrios", como a morte, tal qual os metaleiros, mas vinculados à sonoridade mais melancólica e flertes com música eletrônica e eletro-rock), os glams (que buscam visualização mais andrógena, rompendo as delimitações de gênero, e também vinculados à eletrônica) e os rock-regionalistas (que introduzem elementos sonoros típicos do Nordeste brasileiro, como forró e maracatu, além de indumentária que destaca cores pasteis e adereços também regionais, das populações de baixa renda dos sertões, como sandálias e chapéus de couro).

${ }^{30}$ Referendada por bandas e artistas como Beatles, Pink Floyd, David Bowie, Eric Clapton, Dire Straits, Stone Roses, Radiohead, Oasis, Belle \& Sebastian, Franz Ferdinand, dentre outros.
} 
Essa tipologia de metaleiros e alternativos foi construída em campo, através da visita sistematizada aos eventos e à organização das observações por meio de um caderno de campo, bem como de conversas e entrevistas. Colocar um metaleiro ao lado de um alternativo expõe diferenças muito demarcadas, o que se reflete não apenas em duas vivências bem diferenciadas do estilo de vida roqueiro, mas também numa fronteira que não raro chega à rivalidade.

Antes de abordamos tal rivalidade, vamos analisar como se dá o envolvimento do sujeito com o agrupamento. É preciso entender, antes de tudo, que o tornar-se roqueiro é um processo de adesão. Vivemos em uma sociedade midiática, na qual os bens culturais (música incluso) são consumidos de diversas maneiras. De que maneira é ativada a vinculação por "gosto"? Este é um grande desafio ao sociólogo.

Não temos condições de, no momento, precisar este elemento primeiro, no entanto, há possibilidades mais concretas de análise ao que vem depois. Em outro trabalho (Lima Filho, 2013) refletimos de modo mais detalhado sobre o que podemos chamar de meios de entrada ao estilo de vida roqueiro. Iremos agora apenas rapidamente explicar tal relação.

Primeiramente, há a "descoberta" do elemento agregador, no caso a música rock, por parte do sujeito. Nas entrevistas com os interlocutores da pesquisa, foi possível perceber que, cada um deles, é capaz de afirmar com muita precisão o "exato momento" em que criaram uma vinculação com o rock. Não deve ser coincidência o fato dessa "descoberta" ocorrer sempre em uma faixa etária muito específica, como mostra a Tabela 1 :

TABELA 1 - Idades da "descoberta" do rock

\begin{tabular}{ll}
\hline ROQUEIRO & IDADE \\
\hline Rafael Bandeira & 07 \\
\hline Jolson Ximenes & 09 \\
\hline Amaudson Ximenes & 11 \\
\hline Amanda Silva & 12 \\
\hline Adjacy Farias & 14 \\
\hline Antonio Arruda & 15 \\
\hline Donizete Araújo & 15 \\
\hline Daniel Valentim & 16 \\
\hline Franze Bezerra & 16 \\
\hline
\end{tabular}

Fonte: Entrevistas realizadas pelo autor. 
A "descoberta" está associada ao que chamamos de audição consciente, ou seja, um processo social na qual o agente passa a elaborar significados mais efetivos à música que ouve. Isto leva à criação de vínculos emocionais com a música em geral e, mais precisamente, com um gênero musical em particular.

O rock... Eu posso dizer até o ano e a música, a primeira música que [me] "tocou", assim, né? O ano foi, assim, 1999: eu fazia a 8 a série, aí eles [a família] colocaram MTV, colocaram TV a cabo em casa. [...] A MTV não significava muito até o dia em que eu vi um clipe da Cássia Eller ${ }^{31}$, O Segundo Sol, aquela música... Eu coloco aquela música como o ponto inicial, o pontapé de tudo. [...] Quando você começa a escutar essas coisas [o rock], você começa a prestar atenção e a ver o mundo de outra... [forma] [...]. Bom, aí veio o que mudou a minha vida completamente! (Daniel Valentim, grifos do autor)

O fenômeno que ocorre é um consumo num sentido amplo, tal qual discutido por Certeau (1996) quando conceitua que "consumir" não significa apenas comprar, mas também apreender, apurar e reelaborar. Quer dizer, não importa somente a música "chegar" aos ouvidos do sujeito: é mais importante o processo pelo qual aquela cria um sentido para ele. $\mathrm{O}$ agente reelabora o conteúdo do objeto consumido, lhe dá sentido e cria vínculos com ele. É um tipo de bricolage.

Uma vez que o sujeito é "capturado" pela vinculação àquele elemento cultural específico, parte para o que chamamos de consumo afetivo, um consumo orientado, que pode se dar no campo do consumo mercadológico, mas é movido por uma carga emocional. Este elemento é importante porque, uma vez que está vinculado ao mercado capitalista, este consumo pode ser impulsionado por estratégias de marketing e até dado grau de alienação; porém, o processo inteiro não pode ser reduzido a isso. Uma vez que o consumo afetivo começa a se desenvolver, o sujeito inicia o processo de identificação com a música e começa a localizar outros indivíduos que partilham da mesma vinculação, levando-o aos agrupamentos.

O agrupamento, pelo menos nos casos aqui estudados, não aparece como uma entidade física. Não é um coletivo nitidamente delimitado. É a expressão prática do ser roqueiro orientada dentre uma das possibilidades possíveis (metaleiros, alternativos). É um processo de adesão, mediado por uma "turma" menor.

${ }^{31}$ Cássia Eller, cantora brasileira, lançou o primeiro álbum em 1990 e se tornou uma das cantoras mais populares do país. Morreu em 2001. O segundo sol é uma canção de autoria de Nando Reis, gravada por ela no álbum Com você... Meu mundo ficaria completo, lançado pela Sony Music em 1999. 
Pelo que pudemos apurar nas conversas com os interlocutores e entrevistas, essa adesão quase sempre é realizada por meio da associação entre um iniciado (cicerone) e um novato. A adesão ocorre em nível microssocial, por meio da pequena turma de amigos em espaços privilegiados de sociabilidades, como escola e vizinhança.

Eu tinha um amigo - [eu] era mais novo, tava lá pela minha $8^{a}$ série - que gostava de rock e eu era muito pivete pra saber do que eu gostava, mas comecei a andar, a ouvir rock, com esse meu amigo. [Ele] começou a mostrar o som dele e eu comecei a ver o que eu gostava. (Donizete Araújo)

Eu sempre tive amigos assim [roqueiros] e na escola eu sempre procurava amigos que gostassem mais de rock. Questão de se enturmar. (Amanda Silva)

Geralmente, os cicerones já têm incorporado os valores morais e as regras de comportamento do agrupamento em questão e passam, às vezes sutilmente, outras agressivamente, a apresentá-las aos iniciantes, de modo que este vão aprendendo e as incorporando também.

Como em Fortaleza temos uma rede roqueira articulada, percebemos que essa pequena turma inicial se vincula a dezenas de outras que também professam o agrupamento e se encontram nos espaços roqueiros, sejam festas, shows e festivais ou em pontos de encontros em espaços públicos, como praças.

Dá-se ênfase ao aspecto visual dos roqueiros porque esses signos parecem ativar os sistemas de classificação e facilitam os processos de vínculo do sujeito entre turmas (regionais, comunitárias) e agrupamentos (grupo maior).

Conseguia olhar pra uma pessoa e identificá-la sem você nem ao menos conhecê-la. Então, existia esse respeito por essa representação e por elas estarem simplesmente ali [no clube Canto das Tribos]. [...] Isso era algo assim impulsionador de muita coisa, um criador mesmo de relações, pra criar laços de sociabilidade. (Daniel Valentim, grifos do autor)

A vestimenta, assim, serve não apenas como "identificador" de pares, mas também como forma de adesão e exibição, conferindo um tipo de permissão a fazer parte do agrupamento em si e do ser roqueiro como um todo. É nestes momentos de encontro em que as práticas que orientam o agrupamento são vivenciadas de modo mais nítido, sendo também um grande momento de "prova" na qual são medidas e vigiadas os graus de vinculação do sujeito ao agrupamento de modo mais específico e ao estilo de vida de modo mais geral. 
Você ta no grupo, ele não pede, mas se tiver [no grupo], você vai querer estar parecido. Ninguém te pede, mas você vai querer. Os teus amigos vão te chamar, se tu tiver vestido tal [ou seja, diferente] vão tirar onda contigo, o próprio meio. Se você anda com aquele estilo, você tem que vestir parecido, onde for. [...]. Se tu ta no meio que leva [isso] mais a sério, é natural que você leve mais a sério. [...] Você vai querer andar com as roupas, com alguma coisa parecida, pra mostrar que você se identifica alguma coisa com eles. Então, é uma coisa natural [...]. Não há um grupo, eu não conheço um grupo, em que não tem essa particularidade de as pessoas não quererem usar. [...] É assim que funciona. Roupa é uma coisa que tem a ver, sabe? (Donizete Araújo, grifos do autor)

Claro, os interlocutores naturalizam tal processo em seus discursos, mas é preciso perceber que há algo de opressor em se adequar ao intenso conjunto de códigos relacionados ao ser roqueiro. É neste ponto que aparecem os conflitos já mencionados. A convivência em um agrupamento não é necessariamente pacífica. O ser roqueiro é pautado por valores e regras muito fortes. Neste sentido, guarda elementos do que Simmel (1977) chamou de grupos sociais fechados, ou seja, que impõem regras de conduta mais severas a seus membros e nas quais novos membros podem até ser bem-vindos, desde que cumpram satisfatoriamente uma série de pré-requisitos.

Existem agrupamentos mais fechados do que outros. Metaleiros e punks-hardcores, por exemplo, são bem mais ferrenhos do que outros como alternativos e bluseiros. ${ }^{32}$ Esse "fechamento" não é de modo algum despercebido pelos sujeitos, que relatam tal característica constantemente em suas falas. Vejamos o exemplo de um metaleiro veterano quando pensa em sua própria trajetória:

Teve um período que eu me fechei muito, sabe? [...] Escutava só "podreira", mesmo, só coisa underground, de fita [K7]. [...] A gente não queria saber daquilo ali [outras manifestações], não. Só escutava "porrada" mesmo. Só "porrada", gravação tosca mesmo, underground. (Amaudson Ximenes)

\footnotetext{
32 Os punks-bardcores são aqueles roqueiros mais ligados à tradição do movimento punk e seus desdobramentos. Em Fortaleza há expressões punks propriamente ditas (que são carregadas de mais radicalismo e de posicionamento político crítico) e bardcores (que seria menos extremo, mais calcado na sonoridade e num visual urbano, relacionado, por exemplo, aos skatistas). Uma observação superficial parece sugerir um corte de classe entre punks e hardcores, com os primeiros mais ligados às periferias e os segundos mais embasados nos bairros da Zona Leste. Já os bluseiros são aqueles roqueiros que se vinculam fortemente ao blues, um dos gêneros musicais que deu origem ao rock. Este é um agrupamento menos nítido e que está em processo de formação na cidade.
} 
Simmel (1977) também reparou como os grupos sociais em geral se constituem ou são autopercebidos a partir da distinção de outros. A existência de "outro" a quem se opor fortalece a própria identificação do grupo e isso, definitivamente, ocorre dentro dos agrupamentos. Isso dá início a amplo processo de coerção de seus membros acerca dos valores e regras que compõem as identificações principais que o formam. Estas vão desde partes da visão de mundo mais "adequadas" ao coletivo específico, passando pelo repertório de bandas e artistas cultuados, chegando até ao visual usado.

Essa mediação é operacionalizada por meio dos modos de inclusão $e$ exclusão. Os modos de inclusão são formas de averiguação quanto ao sujeito estar ou não de acordo com os preceitos do agrupamento. São verificados cotidianamente pelos outros membros, num processo no qual o sujeito vai demonstrando as senhas de acesso e mantém-se bem-vindo, como nas falas sobre vestimenta já citadas.

Por outro lado, a observação na pesquisa permite dizer que qualquer deslize é punido, ativando os modos de exclusão, sejam leves (o que gera brincadeiras e chacota), sejam graves (pode gerar represálias, agressões e até a proibição).

Outro entrevistado conta como era "fechado" em determinado momento e como, após passar a tocar outros subgêneros (é baterista), foi excluído dos metaleiros:

Realmente tinha aquela coisa do radicalismo, de que se você não fizesse o som "porrada", você não entrava naquela tribo [os metaleiros]. Se você não fizesse o som hard rock, você também não entrava na tribo. [...] E eu também era um cara radical. Quando eu tava tocando no [conjunto] Procriation, eu só ouvia som "porrada". [...] Nós fomos protagonistas de algumas cenas dessas de radicalismo. [...] A gente [banda Kamerata, heavy metal melódico] fez um show no Teatro do Ibeu, [com outras bandas de metal] [...] e o fato foi que jogaram um saco de merda no vocalista da gente, porque a gente não fazia um som "pesadão", como o dos [outros] caras. (Franzé Bezerra, grifos do autor)

Em torno desses conflitos são construídas as categorias negativas que ativam os modos de exclusão, nos quais os modistas e os playboys são os casos mais representativos. Os primeiros são aqueles acusados de "gostar de rock por moda", ou seja, sujeitos que ouvem (e/ou tocam) rock, mas não cumprem as exigências explícitas da visão de mundo, por isso, são combatidos. É através dessa ferramenta que espaços roqueiros que flertam com o "grande público" (que não seriam roqueiros "de verdade" neste sistema de 
classificação), como o citado Floresta Bar e Restaurante, perdem credibilidade nos setores mais aguerridos da rede.

Já os playboys são aqueles identificados como "tendo grana", quer dizer, advindos da Zona Leste. Como o ser roqueiro está pautado em signos de rebeldia e marginalização, advir das classes altas é desprestígio dentro dos códigos de significação. Desse modo, para se contrapor aos modistas e playboys, surge a categoria dos roqueiros de verdade.

A ideia de uma "defesa" dos códigos típicos do ser roqueiro percebida nos fortalezenses é também comum à história do gênero musical. É nítida a tendência de rupturas (estéticas, valorativas) dentro do rock, da qual o movimento punk, no fim da década de 1970, foi o primeiro e mais célebre exemplo. Como exibem Mcneil e Mcgain (1997), este movimento explicitamente queria romper com o rock mainstream como maneira de se reconectar com suas raízes, suas origens proletárias. Não é por acaso, o forte apelo que o punk teve em contextos muito díspares àquele dos EUA ou Grã-Bretanha, como mostra a pesquisa de Guerra (2013). Os ciclos de rupturas, inspirados pelo punk, continuaram ao longo do tempo, como o bardcore nos anos 1980, o grunge no início dos anos 1990, o indie rock nos anos 2000, etc.

\section{Notas finais: ser roqueiro como estilo de vida}

A partir da discussão apresentada, podemos dizer que ser roqueiro assume a caracterização maior do que "gosto pela arte", sendo a expressão de um estilo de vida, marcado por forte sentimento de pertença, valores morais consolidados e até certo ponto rígidos, normas de conduta específicas e códigos de avaliação do que é permitido e do que não é, manifestado em modos de inclusão e de exclusão.

No mundo contemporâneo, os sujeitos sociais criam uma série de associações dentro dos círculos de sociabilidade ao qual têm acesso. Isso ativa os processos de identificação que nos vinculam a todo o tipo de associação, da qual destacamos os estilos de vida. Giddens (2002) considera como estilo de vida as práticas cotidianas que se rotinizam e passam a orientar a existência social dos indivíduos. Essas práticas "dão forma material a uma narrativa particular da autoidentidade” (ibidem: 79), mas de um modo que conectam aspectos locais a processos sociais mais complexos, de âmbito global. É exatamente isso que o rock realiza enquanto prática, como pudemos perceber. Tais práticas consolidam um conjunto de valores morais e regras de comportamento que precisam ser professados por seus seguidores.

Entender o processo de sociabilidade que leva o sujeito a aderir ao ser roqueiro por meio de um agrupamento diz muito sobre como os agentes sociais desenvolvem as relações entre si mesmos e as estruturas sociais 
mais amplas. Ou seja, é uma boa aplicação prática da tradicional discussão sociológica sobre a interação entre indivíduo e sociedade.

Neste sentido, tal vinculação nos leva a pensar naquilo que Giddens (2009) afirma acerca da agência e da autonomia dos agentes perante o mundo social: o indivíduo não é uma "marionete" das estruturas sociais, mas alguém que reage a elas, processando seu conteúdo e adaptando-o à sua realidade concreta, desejos e possibilidades.

Este artigo procurou analisar a movimentação da rede roqueira em Fortaleza e mostrar a complexidade que envolve o fenômeno social do "gosto" dos jovens por um dado gênero musical. Assim, percebemos o enlace de relações sociais construídas para resultar na expressão prática de um estilo de vida que, apesar de globalizante (já que o rock tem seguidores em todo o mundo), guarda especificidades muito locais.

Estas especificidades mostram como os sujeitos da cidade precisam de algum modo de ultrapassar os desafios impostos pela dinâmica social e articular movimentação de caráter profundo e amplo, mesmo permanecendo no grau da "marginalidade" quanto à visibilidade que tem na própria cidade.

Também procuramos contribuir com elementos de discussão sociológica mais ampla, pensando a maneira como os sujeitos estão interligados ao estilo de vida (de caráter mais global) por meio de sua operacionalização prática através do conceito de agrupamentos e as dinâmicas próprias de inclusão e exclusão desses coletivos sociais.

\section{Referências bibliográficas}

Bhabha, Homi K. (1998), O local da cultura. Belo Horizonte: UFMG.

Bernal, Cleide (2004), A metrópole emergente: a ação do capital imobiliário na estruturação urbana. Fortaleza: Editora UFC/ Banco do Nordeste.

Bourdieu, Pierre (1992), "O mercado de bens simbólicos", in A economia das trocas simbólicas, Coleção Estudos v.20, São Paulo: Perspectiva.

Castells, Manuel (2009), A sociedade em rede, vol. 1. A Era da Informação: economia, sociedade e cultura. São Paulo: Paz e Terra [12. ${ }^{a}$ ed.].

Castro, Wagner (2008), No tom da canção cearense: do rádio e TV, dos lares e bares na era dos festivais (1963-1979). Fortaleza: UFC.

Certeau, Michel de (1996), A invenção do cotidiano: as artes de fazer, vol. 1. Petrópolis: Vozes.

Christe, Ian (2010), Heavy metal: a bistória completa. São Paulo: Arx/Saraiva.

Costa, M. Clélia L.; Pequeno, Renato (orgs.) (2015), Fortaleza: Transformações na ordem urbana. Série Estudos Comparativos. Rio de Janeiro: Letra Capital/ Observatório das Metrópoles. 
Dimery, Robert (org). (2007), 1001 discos para ouvir antes de morrer: selecionados e comentados por 90 críticos de renome internacional. Rio de Janeiro: Sextante.

Diógenes, Glória (1998), Cartografias da cultura e da violência: gangues, galeras e o movimento hip hop. São Paulo: Annablume/ Fortaleza: Secretaria de Cultura e Desporto.

Duarte, Fábio; Frey, Klaus (2008), "Redes urbanas”, in Fábio Duarte; Carlos Quandt; Queila Souza (orgs.), O tempo das redes. Coleção Big Bang. São Paulo: Perspectiva.

Elias, Norbert; Scotson, John L. (2000), Os estabelecidos e os outsiders: sociologia das relações de poder a partir de uma pequena comunidade. Rio de Janeiro: Zahar.

Friedlander, Paul (2002), Rock and roll: uma história social. Rio de Janeiro: Record.

Frith, Simon (1981), Sound Effects: Youth, Leisure and the Politics of Rock'n'Roll. New York: Pantheon.

Frith, Simon (1988), "Rock and the politics of memory", in Sohnya Sayres; Anders Stephanson; Stanley Aronowitz; Fredric Jameson (orgs.), The 60's Without Apology. Minneapolis: University of Minesota Press/Social Text, 59-69.

Giddens, Anthony (2002), Modernidade e identidade. Rio de Janeiro: Zahar.

Giddens, Anthony (2009), A constituição da sociedade. São Paulo: Martins Fontes [3. a ed.].

Goffman, Erwing (1988), Estigma: notas sobre a manipulação da identidade deteriorada. Rio de Janeiro: Guanabara [4. ${ }^{\mathrm{a}}$ ed.].

Guerra, Paula (2013), A instável leveza do rock: gênese, dinâmica e consolidação do rock alternativo em Portugal. Coleção Biblioteca de Ciências Sociais, vol. 88. Porto: Afrontamento.

Hobsbawm, Eric J. (1996), História social do jazz. Rio de Janeiro: Paz e Terra.

Hobsbawm, Eric J. (1997), A era dos extremos: o breve século XX. São Paulo: Companhia das Letras.

Horkheimer, Max; Adorno, Theodor W. (2002), “A indústria cultural: o Iluminismo como mistificação das massas”, in Theodor W. Adorno, Indústria Cultural e Sociedade. São Paulo: Paz e Terra, 07-74 [2. ${ }^{a}$ edição].

IBGE - Instituto Brasileiro de Geografia e Estatística - Cidades@ (2015), "Fortaleza”. Consultado a 01.11.2015, em http://cidades.ibge.gov.br/xtras/perfil.php?lang=\&c odmun=230440\&search=cearalfortaleza.

IPLANFOR (2015), Fortaleza 2040: Iniciando o diálogo por uma Fortaleza de oportunidades, mais justa, bem cuidada e acolhedora, vol. 2, n. ${ }^{\circ}$ 1. Fortaleza: Instituto de Planejamento de Fortaleza.

Lima, Cláudio Ferreira (2006), “Cidades do Ceará: origens transformações e perspectivas”, in Fábio Campos (org.), Anuário do Ceará. Fortaleza: Fundação Demócrito Rocha, 395-452.

Lima Filho, Irapuan Peixoto (2013), Em tudo o que faço, eu procuro ser muito rock and roll: Rock, estilo de vida e rebeldia. Fortaleza: UFC/ Imprensa Universitária.

MacDonald, Ian (2008), Revolution in the Head: The Beatles' Records and the Sixties. London: Vintage Books [3. 'ed. revista]. 
McNeil, Legs; McGain, Gillian (1997), Mate-me por favor: uma história sem censura do punk. Porto Alegre: L\&PM.

Miles, Barry (2009), The British Invasion: The Music, the Times, the Era. London/New York: Sterling.

Morin, Edgar (1999), Cultura de massas no século XX. Vol. 1 e 2. Rio de Janeiro: Forense.

Muggiati, Roberto (1983), Rock - O grito e o mito: a música pop como forma de comunicação e contracultura. Petrópolis: Vozes.

Pais, José Machado (2006), “Bandas de garagem e identidades juvenis”, in Márcia R. da Costa; Elizabeth M. da Silva (orgs.), Sociabilidade juvenil e cultura urbana. São Paulo: Educ/PUC, 29-53.

Roszak, Theodore (1972), A Contracultura: reflexões sobre a sociedade tecnocrática e a oposição juvenil. Petrópolis-RJ: Vozes [2. ${ }^{\text {e ed.]. }}$

Sarlo, Beatriz (1997), Cenas da vida pós-moderna: intelectuais, arte e vídeo-cultura na Argentina. Rio de Janeiro: UFRJ.

Simmel, Georg (1977), Sociología II. Madrid: Biblioteca de la Revista de Occidente.

Souza, Queila; Quandt, Carlos (2008), "Metodologia de análise de redes sociais”, in Fábio Duarte; Carlos Quandt; Queila Souza (orgs.), O tempo das redes. Coleção Big Bang. São Paulo: Perspectiva, 31-63.

Weber, Max (1991), Economia e sociedade. Vol. 1. Brasília: UNB.

Wenner, Jann S.; Levy, Joe (orgs.) (2008), Rolling Stone: As melhores entrevistas da revista Rolling Stone. São Paulo: Larousse.

Artigo recebido a 21.07.2015

Aprovado para publicação a 21.12.2015

\section{Irapuan Peixoto Lima Filho}

Departamento de Ciências Sociais da Universidade Federal do Ceará Av. da Universidade, 2995, CEP. 60.020-180, Fortaleza, Ceará, Brasil

Contacto: irapuanpeixoto@yahoo.com.br 


\section{Noise in Dark Streets: Lifestyle and Social Networks in Rocker Groups}

This research aimed to investigate the formation of roqueiro (rocker or rock fan) groups in the city of Fortaleza, Ceara State, Brazil in the 2000s. It found that they have established their own lifestyle, expressed in their ways of thinking, moral values and behavior patterns, which extends beyond the various music scenes: they have built up a social network, known as the rocker network which has spread throughout the "rich" neighborhoods and "poor" outskirts. This network also allows for the formation of what is termed groupings, i.e. collectives that subdivide the fans into various social groups based on musical styles, such as metaleiros (headbangers), alternativos (alternatives), punks, hardcores, emos, blueseiros (blues fans), etc. Relationships between these groups are not necessarily peaceful, thus paving the way for symbolic disputes to establish status. Keywords: Brazilian rock; lifestyle; music and youth; social networks; sociology of music.

\section{Tapage dans les rues sombres: Style de vie et réseaux sociaux de bandes de rockers}

L' objectif de cette recherche a été de se pencher sur la formation de bandes de rockers, fans du genre musical rock, dans la ville de Fortaleza, Ceará, Brésil, tout au long des années 2000. Nous avons constaté qu'ils professent un style de vie qui leur est propre, qui s'exprime à travers de façons de penser, de valeurs morales et de normes de comportement. Ils meuvent bien plus que des scènes musicales: ils bâtissent un réseau social, dénommé réseau rocker, qui se propage dans les quartiers "riches" et les périphéries. L'organisation en réseau permet aussi la formation de ce que nous appelons de bandes, de collectifs qui fragmentent les adeptes en diverses tendances musicales comme les métalleux, les alternatifs, les punks, les hardcores, les emos, les blueseurs, etc. Leurs rapports ne sont pas forcément pacifiques - des disputes symboliques de légitimité éclatant fréquemment.

Mots-clés: mode de vie; musique et jeunesse; réseaux sociaux; rock brésilien; sociologie de la musique. 
